\title{
Analisis Pektin Albedo Buah Jeruk Pamelo sebagai Adsorben Logam Berat Timbal (Pb), Kadmium (Cd) dan Tembaga (Cu)
}

\author{
(Pectin Analysis of Pamelo Citrus Albedo (Citrus maxima (Burm.f) Merr.) as Adsorbent of \\ Heavy Metal Plumbum (Pb), Cadmium (Cd) and Copper (Cu))
}

\author{
Masdiana Tahir, Ineks Safitri, Asriani Suhaenah \\ Fakultas Farmasi, Universitas Muslim Indonesia, Makassar, Indonesia, 90231
}

Article Info:

Received: 18 March 2018

in revised form: 9 July 2019

Accepted: 3 October 2019

Available Online: 9 October 2019

\section{Keywords:}

Pectin

Pamelo Citrus

Plumbum

Cadmium

Copper

Corresponding Author:

Ineks Safitri

Jurusan Farmasi

Universitas Muslim Indonesia

Makassar 90231

Email: Inezsafitri96@gmail.com

\begin{abstract}
Pamelo citrus is a fruit plant having the potential to be developed in Indonesia. One of the centers for producing large oranges or Pamelo citrus in South Sulawesi is Pangkep Regency. One of the components of the Pamelo citrus is pectin. Pectin is a polysaccharide compound with a high molecular weight which is widely found in plants and it can absorb metals because they contain carboxylic groups. This study aimed to analyze pectin from albedo pamelo citrus fruit as an adsorbent for heavy metal plumbum $(\mathrm{Pb})$, cadmium $(\mathrm{Cd})$ and copper $(\mathrm{Cu})$. The method used was atomic absorption spectrophotometer with the equation analysis of heavy metal adsorption by pectin of pamelo citrus determined by Langmuir and Freundlich adsorption isothermal method. The results showed that pectin of albedo pamelo citrus following the isothermal of Freundlich adsorption which showed the adsorbent capacity of $\mathrm{Pb}, \mathrm{Cd}$ and $\mathrm{Cu}$ with the $\mathrm{KF}$ values $0.561 \mathrm{mg} / \mathrm{g}, 0.010$ $\mathrm{mg} / \mathrm{g}$ and $0.066 \mathrm{mg} / \mathrm{g}$, respectively. Meanwhile, $\mathrm{n}$ values were 0.823 for $\mathrm{Pb}$, 0.321 for $\mathrm{Cd}$ and 1.121 for $\mathrm{Cu}$, and in commercial pectin following the isothermal of Freundlich adsorption with the KF values of $\mathrm{Pb}, \mathrm{Cd}$ and $\mathrm{Cu}$ were $0.650 \mathrm{mg} / \mathrm{g}, \mathrm{Cd} 0.015$ and $\mathrm{Cu}$ of $0.77 \mathrm{mg} / \mathrm{g}$, respectively. Then the $\mathrm{n}$ values were 0.641 for $\mathrm{Pb}, 0.811$ for $\mathrm{Cd}$ and 1.183 for $\mathrm{Cu}$.
\end{abstract}




\begin{abstract}
ABSTRAK
Jeruk pamelo merupakan tanaman buah jeruk yang potensial untuk dikembangkan di Indonesia dan salah satu sentra produksi jeruk besar atau jeruk pamelo di Sulawesi Selatan adalah Kabupaten Pangkep. Salah satu kandungan buah jeruk pamelo adalah pektin. Pektin merupakan senyawa polisakarida dengan bobot molekul tinggi yang banyak terdapat pada tumbuhan dan pektin dapat menyerap logam karena mengandung gugus karboksilat. Penelitian ini bertujuan untuk menganalisis pektin dari buah jeruk pamelo sebagai adsorben logam berat timbal $(\mathrm{Pb})$, kadmium $(\mathrm{Cd})$ dan tembaga $(\mathrm{Cu})$. Metode yang digunakan yaitu spektrofotometer serapan atom dengan analisis persamaan adsorpsi logam berat oleh pektin buah jeruk pamelo ditentukan dengan menggunakan isotermal adsorpsi Langmuir dan Freundlich. Dari hasil penelitian yang diperoleh pektin albedo buah jeruk pamelo mengikuti isotermal adsorpsi Freundlich yang menunjukkan kapasitas adsorben dengan nilai $\mathrm{K}_{\mathrm{F}}$ logam berat $\mathrm{Pb} 0,561 \mathrm{mg} / \mathrm{g}, \mathrm{Cd} 0,010 \mathrm{mg} / \mathrm{g}$ dan $\mathrm{Cu} 0,066 \mathrm{mg} / \mathrm{g}$. sedangkan, nilai $n$ logam berat $\mathrm{Pb}$ 0,823, $\mathrm{Cd}$ 0,321 dan $\mathrm{Cu}$ 1,121 dan pada pektin komersial mengikuti isotermal adsorpsi Freundlich dengan nilai $\mathrm{K}_{\mathrm{F}}$ logam berat $\mathrm{Pb} 0,650 \mathrm{mg} / \mathrm{g}, \mathrm{Cd} 0,015 \mathrm{mg} / \mathrm{g}$ dan $\mathrm{Cu} 0,077 \mathrm{mg} / \mathrm{g}$. Dan nilai $n$ logam berat $\mathrm{Pb} \mathrm{0,641,} \mathrm{Cd} \mathrm{0,811} \mathrm{dan} \mathrm{Cu} 1,183$.
\end{abstract}

Kata kunci: Pektin, Jeruk pamelo, Timbal, Kadmium, Tembaga, Isotermal adsorpsi Langmuir dan Freundlich.

\section{PENDAHULUAN}

Bidang industri di Indonesia pada saat ini berkembang cukup pesat. Perkembangan dunia industri banyak memberikan dampak terhadap kehidupan manusia baik yang positif maupun negatif. Dampak negatif yang dihasilkan adalah peningkatan konsentrasi bahan-bahan pencemar yang mengganggu lingkungan. Hal ini dapat dilihat dengan semakin banyaknya industri yang memproduksi berbagai jenis kebutuhan manusia seperti industri kertas, tekstil, dan penyamakan kulit, dengan adanya pertambahan industri tersebut, maka semakin banyak pula hasil sampingan dan limbah yang akan mencemari lingkungan sekitar, salah satunya adalah logam berat. Limbah logam berat merupakan limbah yang bersifat racun dan berbahaya. Beberapa logam berat yang dapat mencemari lingkungan dan bersifat toksik adalah krom $(\mathrm{Cr})$, perak $(\mathrm{Ag})$, kadmium $(\mathrm{Cd})$, timbal $(\mathrm{Pb})$, seng $(\mathrm{Zn})$, merkuri $(\mathrm{Hg})$, tembaga $(\mathrm{Cu})$, besi $(\mathrm{Fe})$, molibdat $(\mathrm{Mo})$, nikel $(\mathrm{Ni})$, timah $(\mathrm{Sn})$, kobalt (Co) dan unsur-unsur logam ringan seperti arsen (As), aluminium (Al), dan selenium (Purwaningsih, 2009).

Berbagai usaha dilakukan untuk menetralisir pencemaran lingkungan akibat dari logam berat, seperti pemanfaatan berbagai produk biomaterial sebagai penyerap logam. Pemanfaatan dari bahan material ini merupakan alternatif yang dapat dipilih karena memiliki biaya yang minimal dalam proses produksinya. Salah satu biomaterial yang dapat dimanfaatkan sebagai penyerap logam adalah pektin (Wong, et al., 2008).

Jeruk pamelo merupakan tanaman buah yang potensial untuk dikembangkan di Indonesia dan salah satu sentra produksi jeruk besar atau jeruk pamelo di Sulawesi Selatan adalah Kabupaten Pangkep.Telah dilakukan isolasi pektin dengan cara ekstraksi dari buah jeruk pamelo asal Kabupaten Pangkep menggunakan asam klorida $0,2 \mathrm{~N}$ pH 2 pada suhu $80^{\circ} \mathrm{C}$ menghasilkan pektin varietas daging merah $5,74 \%$ dan varietas daging putih $5,73 \%$ dengan karakterisasi pektin yang dihasilkan sesuai dengan standar yang telah ditetapkan dan spektrum hasil analisis FTIR menunjukkan kesesuaian struktur pektin hasil isolasi dengan pektin komersial yaitu terdapat vibrasi $(-\mathrm{OH})$, ikatan $\left(-\mathrm{CH}_{3}\right)$, ikatan $(-\mathrm{C}-\mathrm{H})$, karboksil (-C=O), dan eter (-O-) (Aminah, 2017). Selain itu juga, Sulihono (2012) telah mengisolasi pektin dari buah jeruk pamelo dengan cara ekstraksi menggunakan asam klorida $0,2 \mathrm{~N}$ pada suhu $80^{\circ} \mathrm{C}$ dan lama waktu ekstraksi 120 menit menghasilkan pektin sebesar 26,70 \%. Dan Mery (2017) telah mengisolasi pektin dari kulit jeruk siam dengan 
waktu sentuh optimum yang diperlukan biosorben kulit jeruk siam untuk menyerap timbal adalah pada waktu 60 menit dengan persentasi serapan 99,18\% dan kapasitas serapan sebesar 4,959 mg/g. Kondisi optimum untuk timbal diperoleh pada $\mathrm{pH}$ 4,0 dengan persentasi serapan $97,48 \%$ dan kapasitas serapan sebesar $4,947 \mathrm{mg} / \mathrm{g}$.

Pektin dapat menyerap logam karena mengandung gugus karboksilat. Gugus karboksilat dari pektin dapat bereaksi dengan ion logam berat untuk membentuk senyawa kompleks yang tidak larut dalam air dan dapat diekskresi melalui feses. Reaktivitas pektin terhadap ion logam berat sangat tergantung pada derajat esterifikasinya (Syah, 2010).

\section{METODE PENELITIAN}

\section{Alat dan Bahan}

Alat yang digunakan yaitu pengaduk magnetik (magnetic stirrer), Sentrifuge, Spektrofotometer Serapan Atom (SSA), timbangan analitik (Ohaus Carat Series)

Bahan yang digunakan yaitu albedo buah jeruk pamelo varietas daging merah pangkep, aquades, asam klorida $(\mathrm{HCl})$, etanol $96 \%$, larutan standar $\mathrm{Pb}\left(\mathrm{NO}_{3}\right)_{2} 1000$ ppm (Merck), larutan standar $\mathrm{Cd}\left(\mathrm{NO}_{3}\right)_{2} 1000$ ppm (Merck) dan larutan standar $\mathrm{Cu}\left(\mathrm{NO}_{3}\right)_{2} 1000$ ppm (Merck) dan pektin komersial.

\section{Pengolahan Sampel}

Sampel buah jeruk pamelo (Citrus maxima (Burm.f) Merr.) yang diperoleh dari Kabupaten Pangkep dikupas dan diambil albedonya (lapisan kulit berwarna putih) lalu dibersihkan dan dipotong kecilkecil kemudian dikeringkan menggunakan oven pada suhu $50^{\circ} \mathrm{C}$ hingga kering. Albedo yang telah kering dihaluskan dan diperoleh serbuk albedo buah jeruk pamelo (Huyen, 2014).

\section{Isolasi Pektin dengan Metode Ekstraksi}

\section{Ekstraksi pektin dari albedo buah jeruk pamelo}

Sebanyak 50 gram albedo yang telah diserbukkan ditambahkan aquadest sebanyak 1:20 (Syarifuddin, 2015) lalu diasamkan dengan $\mathrm{HCl} 0,2 \mathrm{~N}$ sampai campuran menjadi $\mathrm{pH} 2$, kemudian dipanaskan pada suhu $80^{\circ} \mathrm{C}$ selama 120 menit (Sutioso, 2012). Selanjutnya dilakukan penyaringan dengan menggunakan kain saring (kain blacu) dan filtrat diambil, kemudian dilakukan pengentalan setengah volume semula dengan pemanasan suhu $80^{\circ} \mathrm{C}$ lalu didinginkan pada suhu kamar (Dewayani, 2014; Aminah, 2017).

\section{Hasil ekstraksi}

Filtrat yang telah didinginkan ditambahkan etanol 96\% yang telah diasamkan dengan perbandingan volume antara etanol $96 \%$ dan filtrat 1:1dan diendapkan selama 12 jam (Sulihono dkk, 2012). Endapan pektin dipisahkan dengan penyaringan menggunakan kertas saring dan dicuci dengan etanol 96\%. Endapan pektin kemudian dikeringkan dalam oven pada temperatur $40^{\circ} \mathrm{C}$ hingga 8 jam.Pektin yang telah kering, kemudian dihaluskan lalu ditimbang dan hitung kadar rendamennya (Hariyati, 2006 ;Aminah, 2017).

\section{Analisis Pektin Buah Jeruk Pamelo sebagai Adsorben Logam Berat Timbal (Pb), Kadmium (Cd) dan Tembaga (Cu)}

Pembuatan larutan standar logam berat $\mathrm{Pb}, \mathrm{Cd}$ dan $\mathrm{Cu}$

Timbal $(\mathrm{Pb})$

Larutan standar $\left(\mathrm{Pb}\left(\mathrm{NO}_{3}\right)_{2}\right) \quad 1000$ ppm diambil sebanyak $5 \mathrm{~mL}$ dimasukkan kedalam labu ukur 50 $\mathrm{mL}$, ditambahkan aquades sampai batas tanda sehingga diperoleh larutan standar $100 \mathrm{ppm}$. Kemudian dibuat larutan standar dengan seri konsentrasi 1, 2, 3, 4 dan 5 ppm.

Kadmium (Cd)

Larutan standar $\mathrm{Cd}\left(\mathrm{NO}_{3}\right)_{2} \quad 1000$ ppm diambil sebanyak $5 \mathrm{~mL}$ dimasukkan kedalam labu ukur 50 $\mathrm{mL}$, ditambahkan aquades sampai batas tanda sehingga diperoleh larutan standar $100 \mathrm{ppm}$. Kemudian dibuat larutan standar dengan seri konsentrasi 1, 2, 3, 4 dan 5 ppm.

Tembaga $(\mathrm{Cu})$

Larutan standar $\mathrm{Cu}\left(\mathrm{NO}_{3}\right)_{2} \quad 1000$ ppm diambil sebanyak $5 \mathrm{~mL}$ dimasukkan kedalam labu ukur 50 $\mathrm{mL}$, ditambahkan aquades sampai batas tanda sehingga diperoleh larutan standar $100 \mathrm{ppm}$. Kemudian dibuat larutan standar dengan seri konsentrasi 1, 2, 3, 4 dan 5 ppm. 
Pembuatan larutan uji logam berat $\mathrm{Pb}, \mathrm{Cd}$ dan $\mathrm{Cu}$

Larutan standar logam berat $\mathrm{Pb}, \mathrm{Cd}$ dan $\mathrm{Cu}$ dengan konsentrasi $100 \mathrm{ppm}$ masing-masing dibuat larutan standar dengan seri konsentrasi 5, 10 dan 15 ppm.

\section{Uji penyerapan pektin komersial sebagai pembanding terhadap logam berat $\mathrm{Pb}, \mathrm{Cd}$ danCu}

Sebanyak 3 buah erlenmeyer disiapkan dan dimasukkan pektin komersial sebanyak 0,5 gram kedalam masing-masing erlenmeyer, kemudian ditambahkan $50 \mathrm{~mL}$ larutan logam berat $\mathrm{Pb}$ dengan konsentrasi 5, 10dan 15 ppm pada setiap erlenmeyer. Selanjutnya diaduk menggunakan pengaduk magnetik (magnetic stirrer) selama 2 jam. Larutan tersebut disentrifugasi dengan kecepatan $3000 \mathrm{rpm}$ selama 5 menit, ambil bagian supernatanya dan ukur kadarlogam dengan menggunakan SSA. Dilakukan perlakuan yang sama untuk logam berat kadmium (Cd) dan tembaga (Cu) (Arlofa, 2015; Wayan, 2014).

\section{Uji penyerapan pektin albedo buah jeruk pamelo terhadap logam berat $\mathrm{Pb}, \mathrm{Cd}$ danCu}

Sebanyak3 buah erlenmeyer disiapkan dan dimasukkan pektin hasil ekstraksi albedo buah jeruk pamelo sebanyak 0,5 gram kedalam masing-masing erlenmeyer, kemudian ditambahkan $50 \mathrm{~mL}$ larutanlogam beratPb dengan konsentrasi 5, 10dan 15 ppm pada setiap erlenmeyer. Selanjutnya diaduk menggunakan pengaduk magnetik (magnetic stirrer) selama 2 jam.Larutan tersebut disentrifugasi dengan kecepatan $3000 \mathrm{rpm}$ selama 5 menit, ambil bagian supernatanya dan ukur kadarlogam dengan menggunakan SSA. Dilakukan perlakuan yang sama untuk logam berat $\mathrm{Cd}$ dan $\mathrm{Cu}$ (Arlofa, 2015; Wayan, 2014).

\section{Analisis Data}

Data yang diperoleh dari spektrofotometer serapan atom digunakan untuk menentukan konsentrasi logam berat yang tersisa setelah proses adsorpsi dengan menggunakan pektin yang dapat dijelaskan dengan dua persamaan isoterm yaitu isoterm Langmuir dan isotherm Freundlich. Isoterm Langmuir didasarkan pada kurva hubungan antara $\mathrm{Ce}$ terhadap $\mathrm{Ce} /(\mathrm{x} / \mathrm{m})$ dan isoterm Freundlich didasarkan pada kurva hubungan antara log Ce terhadap log $(\mathrm{x} / \mathrm{m})$,
Dengan nilai persamaan sebagai berikut :

$$
\begin{aligned}
& C_{a d s}=C_{0}-C_{e} . \\
& x m=\left(C_{0}-C_{e}\right) \times V m \\
& Q=\frac{C_{0}-C e}{C o} \times 100 \%
\end{aligned}
$$

Keterangan :

$\mathrm{C}_{\mathrm{o}}=$ Konsentrasi logam sebelum adsorbsi (ppm)

$\mathrm{C}_{\mathrm{e}}=$ Konsentrasi logam yang tersisa (ppm)

$\mathrm{C}_{\mathrm{ads}}=$ Konsentrasi logam yang teradsorbsi (ppm)

$\mathrm{x} / \mathrm{m}=$ Jumlah mol logam yang teradsorbsi oleh pektin

(mol)

$\mathrm{Q}=$ Presentasi adsorbsi $(\%)$

$\mathrm{V} \quad=$ Volume larutan $(\mathrm{L})$

$\mathrm{m}=$ Berat pektin $(\mathrm{g})$.

\section{HASIL DAN PEMBAHASAN}

Pada penelitian ini telah dilakukan isolasi pektin dari albedo buah jeruk pamelo varietas daging merah asal Kab. Pangkep Sulawesi Selatan. Rendamen yang diperoleh sebesar 7,48 \%. Hasil isolasi pektin dari buah jeruk pamelo dianalisis kapasitas daya serapnya sebagai adsorben terhadap logam berat timbal $(\mathrm{Pb})$, kadmium $(\mathrm{Cd})$ dan tembaga $(\mathrm{Cu})$ dan pektin komersial sebagai pembanding. Proses adsorpsi logam berat yaitu pektin ditambahkan dalam larutan logam dengan konsentrasi yang berbeda kemudian di stirrer selama 2 jam. Filtrat yang dihasilkan diuji dengan menggunakan Spektrofotometer Serapan Atom (SSA).

Analisis kapasitas daya serap pektin sebagai adsorben logam berat $\mathrm{Pb}, \mathrm{Cd}$ dan $\mathrm{Cu}$. Pertama dilakukan pengukuran larutan standar masing-masing logam berat dengan seri konsentrasi 1, 2, 3, 4 dan 5 sehingga diperoleh nilai absorbansi yang hasilnya ditunjukkan pada Tabel 1. 
Tabel 1. Absorbansi larutan standar logam $\mathrm{Pb}, \mathrm{Cd}$, dan $\mathrm{Cu}$

\begin{tabular}{cccc}
\hline Konsentrasi & \multicolumn{3}{c}{ Absorbansi Logam } \\
\cline { 2 - 4 } logam $(\mathrm{ppm})$ & $\mathrm{Pb}$ & $\mathrm{Cd}$ & $\mathrm{Cu}$ \\
\hline 0 & 0,0007 & 0,0007 & 0,0001 \\
1 & 0,0068 & 0,2950 & 0,0859 \\
2 & 0,0203 & 0,5960 & 0,1630 \\
3 & 0,0299 & 0,8547 & 0,2412 \\
4 & 0,0431 & 1,1631 & 0,3134 \\
5 & 0,0547 & 1,3725 & 0,3855 \\
\hline
\end{tabular}

Absorbansi larutan standar logam berat timbal $(\mathrm{Pb})$, kadmium $(\mathrm{Cd})$ dan tembaga $(\mathrm{Cu})$ dibuat kurva baku yaitu plot antara konsentrasi (ppm) dan absorbansi untuk menghasilkan persamaan linier $\mathrm{y}=\mathrm{bx}+\mathrm{a}$. Dari persamaan linier larutan standar akan dihitung nilai absorbansi logam berat $\mathrm{Pb}, \mathrm{Cd}$ dan $\mathrm{Cu}$ yang telah teradsorpsi oleh pektin, dimana akan dihasilkan konsentrasi logam yang tersisa (Nilai $x$ atau $C_{e}$ ).

Setelah dilakukan pengukuran larutan standar logam berat, selanjutnya dilakukan pengukuran larutan uji kapasitas daya serap pektin sebagai adsorben terhadap logam berat $\mathrm{Pb}, \mathrm{Cd}$ dan $\mathrm{Cu}$ dengan seri konsentrasi 5, 10 dan $15 \mathrm{ppm}$ dan dihasilkan nilai absorbansi yang ditunjukkan pada Tabel 2 untuk pektin komersial sebagai pembanding dan Tabel 3 untuk pektin buah jeruk pamelo.

Tabel 2. Absorbansi logam berat $\mathrm{Pb}, \mathrm{Cd}$ dan $\mathrm{Cu}$ yang telah diadsorpsi oleh pektin komersial sebagai pembanding.

\begin{tabular}{cccc}
\hline $\begin{array}{c}\text { Konsentrasi logam } \\
(\mathrm{ppm})\end{array}$ & \multicolumn{3}{c}{ Absorbansi Logam } \\
\cline { 2 - 4 } & $\mathrm{Pb}$ & $\mathrm{Cd}$ & $\mathrm{Cu}$ \\
\hline 5 & 0,002 & 0,081 & 0,081 \\
10 & 0,003 & 0,147 & 0,147 \\
15 & 0,006 & 0,174 & 0,174 \\
\hline
\end{tabular}

Tabel 3. Absorbansi logam berat $\mathrm{Pb}, \mathrm{Cd}$ dan $\mathrm{Cu}$ yang telah diadsorpsi oleh pektin albedo buah jeruk pamelo.

\begin{tabular}{cccc}
\hline $\begin{array}{c}\text { Konsentrasi logam } \\
(\mathrm{ppm})\end{array}$ & \multicolumn{3}{c}{ Absorbansi Logam } \\
\cline { 2 - 4 } & $\mathrm{Pb}$ & $\mathrm{Cd}$ & $\mathrm{Cu}$ \\
\hline 5 & 0,001 & 0,072 & 0,112 \\
10 & 0,004 & 0,119 & 0,239 \\
15 & 0,005 & 0,153 & 0,351 \\
\hline
\end{tabular}

Proses adsorpsi logam $\mathrm{Pb}, \mathrm{Cd}$ dan $\mathrm{Cu}$ oleh pektin albedo jeruk pamelo dan pektin komersial sebagai pembanding dapat dijelaskan dengan dua persamaan isoterm yaitu isoterm Langmuir dan Freundlich, yang digunakan untuk menjelaskan proses absorpsi pada permukaan zat padat. Isoterm Langmuir didasarkan pada kurva hubungan antara $\mathrm{C}_{\mathrm{e}}$ terhadap $\left.\mathrm{C}_{\mathrm{e}} \mathrm{e} / \mathrm{x} / \mathrm{m}\right)$ dan isoterm Freundlich didasarkan pada kurva hubungan antara $\operatorname{Iog} \mathrm{C}_{\mathrm{e}}$ terhadap $\log (\mathrm{x} / \mathrm{m})$ (Wayan, 2014). Hasil adsorpsi logam $\mathrm{Pb}, \mathrm{Cd}$ dan $\mathrm{Cu}$ oleh pektin albedo jeruk pamelo dan pektin komersial dengan parameter-parameter isoterm Langmuir dan Freundlich ditunjukkan pada Tabel 7 dan Tabel 8 . Dari parameter tersebut dapat ditentukan isoterm adsorpsi logam $\mathrm{Pb}, \mathrm{Cd}$ dan $\mathrm{Cu}$ oleh pektin albedo buah jeruk pamelo dan pektin komersial dengan membandingkan koefisien korelasinya $\left(\mathrm{R}^{2}\right)$ untuk menghasilkan kapasitas adsorpsi suatu adsorben.

Untuk menentukan nilai kapasitas adsorpsi logam dapat ditentukan dengan nilai $\mathrm{K}_{\mathrm{F}}$ yang menunjukkan kapasitas serapan suatu adsorben, semakin besar nilai $\mathrm{K}_{\mathrm{F}}$ maka semakin besar pula kapasitas adsorben menyerap adsorbat dan nilai $\mathrm{n}$ menunjukkan derajat nonlinieritas antara konsentrasi larutan adsorpsi, yaitu mengukur penyimpangan linieritas adsorpsi dan biasanya digunakan untuk mengetahui tingkat kebenaran suatu adsorpsi dengan nilai $n<1$, maka dapat dipastikan bahwa adsorpsi ini merupakan proses kemisorpsi dan sebaliknya jika $>1$, dipastikan bahwa adsorpsi yang terjadi merupakan proses fisiosorpsi (Ozcan, 2005). 
Tabel 4. Parameter-parameter isoterm Langmuir dan Freundlich logam berat oleh pektin komersial sebagai pembanding.

\begin{tabular}{ccccccccc}
\hline Logam Berat & $\mathrm{C}_{\mathrm{o}}$ & $\mathrm{C}_{\mathrm{e}}$ & $\mathrm{C}_{\mathrm{ads}}$ & $\mathrm{x} / \mathrm{m}$ & $\begin{array}{c}\mathrm{C}_{\mathrm{e}} / \\
(\mathrm{x} / \mathrm{m})\end{array}$ & $\log \mathrm{C}_{\mathrm{e}}$ & $\operatorname{Logx} / \mathrm{m}$ & $\begin{array}{c}\mathrm{Q} \\
(\%)\end{array}$ \\
\hline \multirow{3}{*}{$\mathrm{Pb}$} & 5 & 0,363 & 4,637 & 0,115 & 3,156 & $-0,440$ & $-0,939$ & 92,74 \\
& 10 & 0,454 & 9,546 & 0,238 & 1,907 & $-0,342$ & $-0,623$ & 95,46 \\
& 15 & 0,727 & 14,273 & 0,368 & 1,975 & $-0,138$ & $-0,434$ & 95,15 \\
$\mathrm{Cd}$ & 5 & 2,737 & 2,263 & 0,056 & 48,875 & 0,437 & $-1,251$ & 45,26 \\
& 10 & 5,725 & 4,275 & 0,106 & 54,009 & 0,757 & $-0,974$ & 42,75 \\
& 15 & 6,937 & 8,063 & 0,201 & 34,512 & 0,841 & $-0,696$ & 53,75 \\
$\mathrm{Cu}$ & 5 & 1,263 & 3,737 & 0,093 & 13,580 & 0,101 & $-1,031$ & 74,74 \\
& 10 & 2,697 & 7,303 & 0,182 & 14,818 & 0,430 & $-0,739$ & 73,03 \\
& 15 & 4,394 & 10,606 & 0,265 & 16,581 & 0,642 & $-0,576$ & 70,70 \\
\hline
\end{tabular}

Tabel 5. Parameter-parameter isoterm Langmuir dan Freundlich logam berat oleh pektin buah jeruk pamelo.

\begin{tabular}{ccccccccc}
\hline $\begin{array}{c}\text { Logam } \\
\text { Berat }\end{array}$ & $\mathrm{C}_{\mathrm{o}}$ & $\mathrm{C}_{\mathrm{e}}$ & $\mathrm{C}_{\mathrm{ads}}$ & $\mathrm{x} / \mathrm{m}$ & $\begin{array}{c}\mathrm{C}_{\mathrm{e}} / \\
(\mathrm{x} / \mathrm{m})\end{array}$ & $\log \mathrm{C}_{\mathrm{e}}$ & $\operatorname{Iog} \mathrm{x} / \mathrm{m}$ & $\begin{array}{c}\mathrm{Q} \\
(\%)\end{array}$ \\
\hline \multirow{2}{*}{$\mathrm{Pb}$} & 5 & 0,272 & 4,728 & 0,118 & 2,305 & $-0,565$ & $-0,928$ & 94,56 \\
& 10 & 0,545 & 9,455 & 0,236 & 2,309 & $-0,263$ & $-0,627$ & 94,55 \\
& 15 & 0,636 & 14,364 & 0,359 & 1,771 & $-0,196$ & $-0,444$ & 95,76 \\
$\mathrm{Cd}$ & 5 & 2,337 & 2,663 & 0,066 & 35,409 & 0,368 & $-1,180$ & 53,26 \\
& 10 & 4,462 & 5,538 & 0,138 & 32,333 & 0,649 & $-0,860$ & 55,38 \\
& 15 & 5,987 & 9,013 & 0,225 & 26,608 & 0,777 & $-0,647$ & 60,08 \\
$\mathrm{Cu}$ & 5 & 1,394 & 3,606 & 0,090 & 15,488 & 0,144 & $-1,045$ & 72,12 \\
& 10 & 3,065 & 6,935 & 0,173 & 17,716 & 0,486 & $-0,761$ & 69,35 \\
& 15 & 4,539 & 10,461 & 0,261 & 17,390 & 0,656 & $-0,583$ & 69,74 \\
\hline
\end{tabular}

Pada proses fisiosorpsi gaya yang mengikat adsorbat oleh adsorben adalah gaya van der waals. Molekul terikat sangat lemah dan energi yang dilepaskan pada adsorpsi fisika relatif rendah. Sedangkan pada proses adsorpsi kimia (kemisorpsi), interaksi adsorbat dengan adsorben melalui pembentukan ikatan kimia. Kemisorpsi terjadi diawali dengan adsorpsi fisik, yaitu partikel-partikel adsorbat mendekat ke permukaan van der waals atau melalui ikatan hidrogen. Kemudian diikuti oleh adsorpsi kimia yang terjadi setelah adsorpsi fisika. Dalam adsorpsi kimia partikel melekat pada permukaan dengan membentuk ikatan kimia (biasanya ikatan kovalen) dan cenderung mencari tempat yang memaksimumkan bilangan koordinasi dengan substrat. Mekanisme proses adsorpsi dapat digambarkan sebagai proses dimana molekul meninggalkan larutan dan menempel pada permukaan zat adsorben secara kimia dan fisika (Atkins, 1999).
Konsentrasi larutan juga berpengaruh terhadap adsorpsi. Semakin tinggi suatu zat terlarut, maka semakin banyak pula zat terlarut yang dapat diadsorpsi oleh adsorben. Berdasarkan koefisien korelasi $\left(\mathrm{R}^{2}\right)$ yang diperoleh dari isoterm Langmuir dan isoterm Freundlich menunjukkan bahwa adsorpsi yang lebih sesuai dengan adsorpsi logam timbal oleh pektin komersial adalah isotermal Freundlich dibandingkan dengan model isotermal Langmuir. Hal ini bisa dilihat dari nilai $\mathrm{R}^{2}$ persamaan isotermal Freundlich yaitu 0,886 sedangkan untuk persamaan isotermal Langmuir adalah 0,432. Berdasarkan isotermal Freundlich nilai $\mathrm{K}_{\mathrm{F}}$ diperoleh sebesar 0,650 $\mathrm{mg} / \mathrm{g}$ dan nilai $n$ sebesar 0,641.Untuk logam $\mathrm{Cd}$ menunjukkan bahwa adsorpsi yang lebih sesuai dengan adsorpsi logam $\mathrm{Cd}$ oleh pektin komersial adalah isotermal Freundlich dibandingkan dengan model isotermal Langmuir. Hal ini bisa dilihat dari nilai $\mathrm{R}^{2}$ persamaan isotermal Freundlich yaitu 0,897 sedangkan untuk persamaan isotermal Langmuir 
adalah 0,274. Berdasarkan isotermal Freundlich nilai $\mathrm{K}_{\mathrm{F}}$ diperoleh sebesar $0,015 \mathrm{mg} / \mathrm{g}$ dan nilai $n$ sebesar 0,811.Untuk logam $\mathrm{Cu}$ menunjukkan bahwa adsorpsi yang lebih sesuai dengan adsorpsi logam $\mathrm{Cu}$ oleh pektin komersial adalah isotermal Freundlich dibandingkan dengan model isotermal Langmuir. Hal ini bisa dilihat dari nilai $\mathrm{R}^{2}$ persamaan isotermal Freundlich yaitu 0,998 sedangkan untuk persamaan isotermal Langmuir adalah 0,997. Berdasarkan isotermal Freundlich nilai $\mathrm{K}_{\mathrm{F}}$ diperoleh sebesar 0,077 $\mathrm{mg} / \mathrm{g}$ dan nilai $n$ sebesar 1,183 .

Untuk pektin albedo buah jeruk pamelo menunjukkan bahwa adsorpsi yang lebih sesuai dengan adsorpsi logam $\mathrm{Pb}$ oleh pektin albedo buah jeruk pamelo adalah isotermal Freundlich dibandingkan dengan model isotermal Langmuir. Hal ini bisa dilihat dari nilai $\mathrm{R}^{2}$ persamaan isotermal Freundlich yaitu 0,955 sedangkan untuk persamaan isotermal Langmuir adalah 0,474. Berdasarkan isotermal Freundlich nilai $\mathrm{K}_{\mathrm{F}}$ diperoleh sebesar $0,561 \mathrm{mg} / \mathrm{g}$ dan nilai $n$ sebesar 0,823. Untuk logam Cd menunjukkan bahwa adsorpsi yang lebih sesuai dengan adsorpsi logam kadmium oleh pektin albedo buah jeruk pamelo adalah isotermal Freundlich dibandingkan dengan model isotermal Langmuir. Hal ini bisa dilihat dari nilai $\mathrm{R}^{2}$ persamaan isotermal Freundlich yaitu 0,978 sedangkan untuk persamaan isotermal Langmuir adalah 0,930. Berdasarkan isotermal Freundlich nilai $\mathrm{K}_{\mathrm{F}}$ diperoleh sebesar $0,010 \mathrm{mg} / \mathrm{g}$ dan nilai $n$ sebesar 0,321. Untuk logam $\mathrm{Cu}$ menunjukkan bahwa adsorpsi yang lebih sesuai dengan adsorpsi logam tembaga oleh pektin albedo buah jeruk pamelo adalah isotermal Freundlich dibandingkan dengan model isotermal Langmuir. Hal ini bisa dilihat dari nilai $\mathrm{R}^{2}$ persamaan isotermal Freundlich yaitu 0,996 sedangkan untuk persamaan isotermal Langmuir adalah 0,659. Berdasarkan isotermal Freundlich nilai $\mathrm{K}_{\mathrm{F}}$ diperoleh sebesar $0,066 \mathrm{mg} / \mathrm{g}$ dan nilai $n$ sebesar 1,121 .

Berdasarkan hasil nilai kapasitas adsorpsi terhadap logam berat timbal $(\mathrm{Pb})$, kadmium $(\mathrm{Cd})$ dan tembaga $(\mathrm{Cu})$ yang didapatkan yaitu nilai $\mathrm{K}_{\mathrm{F}} \operatorname{logam}$ berat $\mathrm{Pb}$ pektin komersial lebih besar dibandingkan pektin albedo buah jeruk pamelo dan nilai $n<1$ maka proses adsorpsi termasuk proses kemisorpsi. Pada nilai $\mathrm{K}_{\mathrm{F}}$ logam berat $\mathrm{Cd}$ pektin albedo buah jeruk pamelo lebih besar dibandingkan pektin komersial dan nilai $n<1$ maka proses adsorpsi termasuk proses kemisorpsi. Sedangkan nilai $\mathrm{K}_{\mathrm{F}}$ logam berat $\mathrm{Cu}$ pektin albedo buah jeruk pamelo lebih besar dibandingkan pektin komersial dan nilai $n>1$ maka proses adsorpsi termasuk proses fisiosorpsi. Dan persentasi adsorpsi Q (\%) untuk masing-masing konsentrasi logam berat $\mathrm{Pb}, \mathrm{Cd}$ dan $\mathrm{Cu}$ menunjukkan persentasi adsorpsi logam yang tidak berbeda jauh dan semakin tinggi konsentrasi logam maka semakin besar persentasi adsorpsinya.

\section{KESIMPULAN}

Berdasarkan hasil penelitian yang telah dilakukan, maka dapat disimpulkan bahwa :

1. Pektin buah jeruk pamelo memiliki daya serap terhadap logam berat timbal $(\mathrm{Pb})$, kadmium $(\mathrm{Cd})$ dan tembaga $(\mathrm{Cu})$.

2. Persentasi adsorpsi pektin albedo buah jeruk pamelo terhadap persentasi adsorpsi pektin komersial tidak berbeda jauh.

3. Pektin albedo buah jeruk pamelo mengikuti isotermal adsorpsi Freundlich dengan nilai $\mathrm{K}_{\mathrm{F}}$ logam berat $\mathrm{Pb} 0,561 \mathrm{mg} / \mathrm{g}, \mathrm{Cd} 0,010 \mathrm{mg} / \mathrm{g}$ dan $\mathrm{Cu} 0,066 \mathrm{mg} / \mathrm{g}$ dan nilai $n$ logam berat $\mathrm{Pb} 0,823$, $\mathrm{Cd} 0,321$ dan $\mathrm{Cu}$ 1,121. Dan pektin komersial mengikuti isotermal adsorpsi Freundlich dengan nilai $\mathrm{K}_{\mathrm{F}}$ logam berat $\mathrm{Pb} 0,650 \mathrm{mg} / \mathrm{g}, \mathrm{Cd} 0,015$ $\mathrm{mg} / \mathrm{g}$ dan $\mathrm{Cu} 0,077 \mathrm{mg} / \mathrm{g}$ dan nilai $n$ logam berat $\mathrm{Pb} 0,641, \mathrm{Cd} 0,811$ dan $\mathrm{Cu} 1,183$.

\section{DAFTAR PUSTAKA}

Aminah, T. M., \& Andriani, R. (2017). Isolasi dan Karakterisasi Pektin dari Albedo Buah Jeruk Pamelo (Citrus maxima (Burm.f) Merr.). Poster Ilmiah Seminar Nasional Kefarmasian STIFA Makassar.

Arlofa, N. (2015). Pektin Kulit Durian sebagai Bahan Baku Biosorben Logam Berat Timbal $(\mathrm{Pb})$. Universitas Serang Raya. Banten.

Atkins, P. W. (1999). Kimia Fisika ed ke-2. Erlangga: Jakarta.

Dewayani, W. (2014). Isolasi dan Karakterisasi Pektin dari Kulit Jeruk Besar Pangkep. Thesis. Fakultas MIPA UNHAS. Makassar.

Hariyati, M. N. (2006). Ekstraksi dan Karakterisasi Pektin dari Limbah Proses Pengolahan Jeruk Pontianak (Citrus nobilis Var Microcarpa). 
Skripsi. Fakultas Teknologi Pertanian IPB. Bogor.

Huyen, V. T. N., \& Quoc, L. P. T. (2014). Extraction of Pectin from Pamelo (Citrus maxima) Peels with The Assistance of Microwave and Tartaric Acid. International Food Research Journal, 22(4),1637-1641.

Mery, N. (2017). Bioadsorpsi Pb(II) Menggunakan Kulit Jeruk Siam (Citrus reticulata). Pendidikan Kimia Universitas Tadulako. Palu, 160-164.

Ozcan, A. S. (2005). Adsorption of Acid Blue 193 From Aqueous Solution onto BTMA-Bentonit Colloid Surface. Journal Physycochemical Engineering Aspect, 73-81.

Purwaningsih, D. (2009). Adsorpsi multi logam $\mathrm{Ag}(\mathrm{I}), \mathrm{Pb}(\mathrm{II}), \mathrm{Cr}(\mathrm{III}), \mathrm{Cu}(\mathrm{II}), \mathrm{Ni}(\mathrm{II})$ pada silica dari abu sekam padi, Jurnal Penelitian Saintek, 14(1), 59-76.

Sulihono, A. (2012). Pengaruh Waktu, Temperatur, dan Jenis Pelarut Terhadap Ekstraksi Pekti dari Kulit Jeruk Bali (Citrus maxima). Skripsi. Teknik Kimia Universitas Sriwijaya. Palembang.

Sutioso, H. (2012). Pemanfaatan Pektin yang Diisolasi dari Daun Jambu Biji (Psidii guajava) dalam Uji In vitro dan In vivo Penurunan Kadar Kolestrol. Skripsi. Fakultas Teknik UI. Jakarta.

Syah, M. (2010). Daya Serap Pektin Dari Kulit Buah Durian (Durio zibethinus) Terhadap Logam Tembaga dan Seng, Skripsi. Universitas Sumatera Utara. Medan.

Wayan, S. I. (2014). Adsorpsi Ion Logam $\mathrm{Cu}^{2+}$ pada Pektin dari Kulit Pisang Tongka Langit, Ambon. Jurnal Chemistry Department Faculty of Mathematics and Natural Sciences Pattimura University, 2(1), 72-73.

Wong, W.W., Abbas F. M. A., Liong, M.T., \& Azhar, M.E. (2008). Modification of Durian Rind Pectin for Improving Biosorbent Ability, International Food Research Journal, 15(3). 